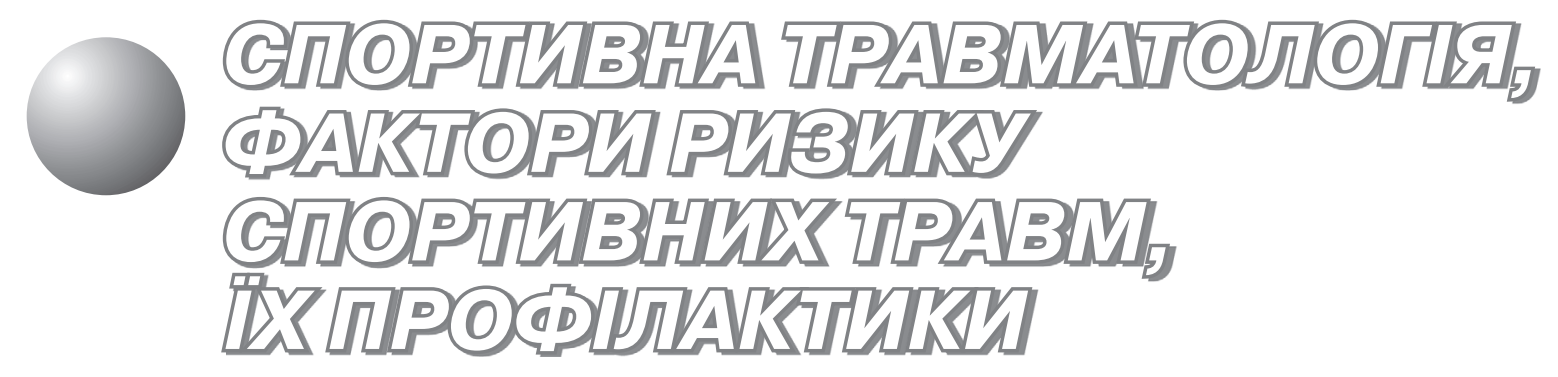

DOI: https://doi.org/10.32652/spmed.2020.1.61-63

\title{
Структурно-функціональні особливості п'яткового (ахіллового) сухожилка, етіологія, патогенез пошкодження
}

\section{УДК 617-089.844}

\author{
О. К. Ніканоров, В. Б. Заєць
}

Національний університет фізичного вихованя і спорту України, Київ, Україна

Резюме. Мета. Огляд вітчизняної та закордонної літератури з приводу проблем виникнення пошкодження п'яткового (ахіллового) сухожилка для подальшого планування лікування та реабілітації пацієнтів. Триголовий м'яз гомілки та його сухожилки перекидаються через три суглоби: колінний, надп'ятково-гомілковий та підтаранний. Фібрили сухожилка ротуються 3 середини до зовні на 90 град. Це дозволяє передавати скорочення з усіх волокон м'яза на один з країв місця прикріплення. Етіологія пошкодження сухожилка мультифакторіальна. Серед причин розриву п'яткового сухожилка виділяють: спортивну травму, побутову травму, спонтанний розрив (без механічної причини), відкрите пошкодження. Висновки. Консервативні методи відновлення спонтанного розриву п'яткового сухожилка (гіпсова іммобілізація, ходьба в ортезі) не дозволяють досягти задовільних результатів у спортсменів та у пацієнтів, що активно займаються фізичною діяльністю. Врахування особливостей виникнення пошкодження п'яткового сухожилка дозволяють застосовувати найбільш ефективні методики профілактики, оперативного відновлення та реабілітації пацієнтів з даною патологією. Ключові слова: п'ятковий (ахілловий) сухожилок, етіологія, патогенез, пошкодження.

\section{Structural and functional peculiarities of the Achilles tendon, etiology and pathogenesis of rupture}

\section{O. K. Nikanorov, V. B. Zaiets}

National University of Physical Education and Sport of Ukraine, Kyiv, Ukraine

Abstract. Objective. Review of the national and foreign literature on the problem of Achilles tendon rupture for further planning of treatment and rehabilitation of patients. The triceps muscle of calf and its tendons are thrown over three joints: the knee, the ankle and the foot. The tendon fibrils rotate from the middle to the outside by 90 degrees. This allows transferring contraction from all muscle fibers to one of the edges of the attachment site. The etiology of tendon rupture is multifactorial. The reasons for the rupture of the Achilles tendon are: sports injury, personal injury, spontaneous rupture (without mechanical reason), open damage. Conclusions. Conservative methods for treatment of spontaneous Achilles tendon rupture (immobilization, walking in an orthopedic shoes) fail to achieve satisfactory outcomes in athletes and patients actively engaged in physical activity. Taking into account the peculiarities of the occurrence of the Achilles tendon damage allow to apply the most effective methods of prevention, operative restoration and rehabilitation of patients with this pathology.

Keywords: achilles tendon, etiology, pathogenesis, damage. 
Постановка проблеми. П'ятковий (ахілловий) сухожилок $\epsilon$ найбільшим сухожилля у людини, має межу міцності на розрив від 50 до 100 N/мм. Він фоормується при з'єднанні двох сухожилків камбалоподібного та литкового м'язів [1]. Не дивлячись на таку міцність, п'ятковий сухожилок відноситься до найчастіше травмованих у людини і займає третє місце після розривів ротаторної манжети та квадрицепса. У світі спостерігається зростання частоти пошкоджень п'яткового сухожилка. Так, за даними іноземних авторів, у 2001 р. частота розривів становила 47 випадків серед чоловіків та 12 випадків серед жінок на 100 тис. населення. А в 2012 р. кількість випадків дорівнювала 55 та 15 відповідно. Таким чином частота розривів збільшилась на $17 \%$ у чоловіків та на $22 \%$ у жінок $[3,4,6$,$] . Проб-$ лема пошкоджень п'яткового сухожилка актуальна тим, що найбільш часто розрив трапляється у працездатних та фрізично активних осіб віком 30-40 років. Це можна пояснити, з однієї сторони, розвитком дегенеративних процесів у тканині сухожилка, а з іншої - зростанням кількості «спортсменів вихідного дня», коли заняття спортом відбуваються періодично, з великими проміжками. На фоні зростання частоти травмування сухожилка зберігаються проблеми практично на всіх етапах відновлення функції, починаючи із труднощів діагностики, високої частоти ускладнень та реруптур при лікуванні, відсутністю адекватної реабілітації $[5,7]$. Все це призводить до незадовільних фрункціональних результатів лікування даної групи пацієнтів. Частота помилок під час встановлення діагнозу розрив п'яткового сухожилка на сьогодні зменшилась, проте залишається на високому рівні: так, у 1984 р. 40 \%, а в 2010 р. - $22 \%$ [2, 3]. На етапі хірургічного лікування існує проблема із загоєнням операційної рани, пошкодження литкового нерва, реруптури. Також існує проблема вибору шва сухожилка, що впливає на терміни іммобілізації, особливості реабілітації. Залишаються не вирішеними варіанти мобілізації, строків мобілізації, початку осьового навантаження.

Мета дослідження - огляд вітчизняної та зарубіжної літератури з приводу виникнення пошкодження п'яткового сухожилка для подальшого планування лікування та реабілітації пацієнтів.

Результати дослідження. Анатомічна будова. Литковий м'яз бере початок двома головками від підколінної поверхні стегнової кістки над виростками стегна. У середній третині гомілки головки, що з'єднуються між собою, переходять у широкий сухожилок, який поступово звужується в дистальному напрямку та зливається з сухожилком камбалоподібного (п'яточного) м'яза, продовжується в масивний п'ятковий сухожилок (tendo calcaneus Achillis) та прикріплюється до задньої поверхні п'яточного бугра. У місці прикріплення знаходиться сумка сухожилка. П'ятковий, або камбалоподібний, м'яз знаходиться під литковим, де бере початок від головки та верхньої третини задньої поверхні малогомілкової кістки, далі спускається вздовж лінії камбалоподібного м'яза на великогомілковій кістці до межі середньої та нижньої третини гомілки. На початку кріплення, у проксимальному відділі, коли м'яз перекидається від малогомілкової кістки до великогомілкової, утворюється сухожильна дуга, під якою проходять підколінна артерія та великогомілковий нерв. Прямуючи дистально, волокна п'яткового м'яза переходять у широке сухожилкове розтяжіння, котре зливається з волокнами від литкового м'яза та формує загальний сухожилок. П'ятковий сухожилок сполучає медіальну та латеральну головки литкового та камбалоподібного м'язів в одне ціле - триголовий м'яз гомілки (m. triceps surae). Цей м'яз та його сухожилки перекидаються через три суглоби: колінний, надп'ятково-гомілковий та підтаранний. Фібрили сухожилка ротуються 3 середини до зовні на 90 град. Це дозволяє передавати скорочення з усіх волокон м'яза на один з країв місця прикріплення [7, 8]. Кровопостачання п'яткового сухожилка здійснюється в проксимальних відділах за рахунок задньої великогомілкової артерії, а в дистальних - артеріальної сітки, що бере початок від розгалуджень малогомілкової та задньої великогомілкової артерії на рівні п'яткової кістки. Безпосередньо трофріка сухожилка відбувається за рахунок судин, котрі проходять через брижу паратенона. Також судини проходять на рівні дистального кріплення до п'яткової кістки та в сухожилко-м'язевому переході. Кількість судин зменшується проксимально та досягає мінімума через 4-5 см від п'яткового бугра [1,3].

Етіологія пошкодження п'яткового сухожилка - мультифракторіальна. Серед причин його розриву виділяють: спортивну травму, побутову травму, спонтанний розрив (без механічної причини), відкрите пошкодження, яке трапляється частіше у чоловіків $(56,4 \%)$. Серед спортивної травми лідерами також $є$ чоловіки (66,2 \%), а поміж тих, хто отримав побутову травму, більшість становлять жінки (39,9 \%). Серед осіб зі спортивною травмою у $15,4 \%$ пацієнтів в анамнезі мав місце біль в ділянці п'яткового сухожилка, а у 7,4 \% мало місце використання глюкокортикостероїдів. Водночас у пацієнтів, 
котрі отримали спонтанний розрив, або травму в побуті, біль траплявся у $37 \%$ випадків та у 19,3 \% передувало використання глюкокортикоїдів. Ці дані підтверджують теорію, що розрив частіше виникає саме у дегенеративно зміненому сухожилку (56,3%). Також пошкодження лівого сухожилка зустрічалось частіше, ніж правого. Можливо тому, що у більшості осіб сильнішою $€$ права нога [3, 5].

Патогенез. П'ятковий сухожилок має широку площу кріплення, котре розташоване нижче верхівки п'яточної кістки. Еластичні волокна переходять спочатку в некальцифріковану, а потім у кальцифріковану грубоволокнисту хрящову тканину, яка змінюється на кісткову. Це дозволяє пояснити френомен «зони відриву», що розташована на межі переходу еластичної тканини (сухожилка) в нееластичну (кістка) [8]. П'ятковий сухожилок як біологічна тканина має високі еластичні властивості: під час кроку та розтягнення еластичних фрібрил близько $6 \%$ енергії кумулюється у волокнах сухожилках, де при поштовху ноги вона вивільнюється. Під час бігу можлива кумуляція енергії до 16 \%. Проте розтягнення еластичних волокон можливе лише до $10 \%$ загальної довжини сухожилка. При перевищенні цього показника відбуваются незворотні зміни на рівні фрібринових волокон, і довжина сухожилка не відновлюється $[5,6]$. Фібрилові волокна починають ушкоджуватись при розтягненні сухожилка на $4 \%$, та розриваються при збільшенні розтягнення до $8 \%$. Як відомо, основне кровопостачання відбувається через судини мезоте-

\section{Література}

1. Коструб ОО, Заєць ВБ, Засаднюк IA, Блонський РІ. Метод оперативного лікування спонтанного розриву ахіллового сухожилка [The method of operative treatment of spontaneous Achilles tendon rupture]. Спортивна медицина. 2013; 1: 81-6.

2. Левенець ВМ, Майко ВМ. Ушкодження і захворювання п'яткового (ахіллового) сухожилка [Damage end disorders of the Achilles tendon]. Київ, 2010. 216 c.

3. Середа АП. Хирургическое лечение разрывов ахиллова сухожилия [Surgical treatment of the Achilles tendon ruptures]: диссертация. Москва, 2014. 324 с. нона та мезентерію, що розташований попереду сухожилка. Розрив найчастіше локалізується на відстані 2-6 см від прикріплення сухожилка до п'яткової кістки у зоні з відносно бідним кровопостачанням [4]. Спонтанний розрив спостерігається у практично здорових осіб, але при гістологічному дослідженні виявляються дегенеративні зміни у тканині сухожилка. Починаючи з 30 років, має місце зменшення діаметра та щільності розташування колагенових волокон сухожилка, що зменшує регенеративні можливості останнього. Застосування фрторхінолонів та стероїдів збільшує ризик спонтанного розриву п'яткового сухожилка. Місцева гіпертермія та ішемія тканин веде до виникнення дегенеративних змін у тканині п>яточного сухожилка. Порушення режиму тренування та хронічна травматизація п'яти при гіперпронації стопи також призводять до виникнення пошкоджень п'яткового сухожилка [3, 5, 9]. 3 огляду на це, консервативні методи відновлення спонтанного розриву п'яткового сухожилка (гіпсова іммобілізація, ходьба в ортезі) не дозволяють досягти задовільних результатів у спортсменів та у пацієнтів, котрі активно займаються фрізичною діяльністю, оскільки не можуть забезпечити потрібний натяг сухожилка, що зростається [2, 3].

\section{Висновки}

Врахування особливостей виникнення пошкодження п'яткового сухожилка дозволяють застосовувати найбільш ефективні методики профрілактики, оперативного відновлення та реабілітації пацієнтів з даною патологією.

4. Calder J, et al. Disorders of the Achilles tendon insertion. 2012; 218

5. Karlsson J, et al. Achilles tendon disorders. 2014; 426.

6. Maffulli N, Oliva F. Achilles tendon. 2009; 105.

7. Maffulli N, et al. Achilles tendinopathy. 2010; 214.

8. Murthy GA, et al. Achilles tendon. Foot and ankle clinics. 2009 Dec; 14(4): 618-804.

9. Niek van Dijk C, et al. Achilles tendon rupture. 2008; 124 